\title{
Penerapan metode penemuan terbimbing (guided discovery) untuk meningkatkan kreativitas berfikir bagi siswa kelas VIII-A SMPN 1 Turen
}

\author{
Fadilah Hapsari, Ety Tejo Dwi Cahyowati* \\ Universitas Negeri Malang, Jl. Semarang No. 5 Malang, Jawa Timur, Indonesia \\ *Penulis korespondensi, Surel: ety.tejo.fmipa@um.ac.id
}

Paper received: 01-12-2021; revised: 15-12-2021; accepted: 31-12-2021

\begin{abstract}
Abstrak
Metode penelitian ini merupakan Penelitian Tindakan Kelas dengan dua siklus. Tujuan penelitian ini adalah mendeskripsikan langkah-langkah pembelajaran menggunakan metode penemuan terbimbing yang dapat meningkatkan kreativitas berpikir siswa. Tahap-tahap metode penemuan terbimbing yang diterapkan adalah tahap observasi, merumuskan masalah, mengajukan hipotesis, merencanakan pemecahan masalah, melakukan eksperimen, dan pengumpulan data atau analisis data. Hasil penelitian tindakan kelas ini menunjukkan kreativitas siswa meningkat sebanyak 12,3 persen, yang menggambarkan bahwa metode penemuan terbimbing dapat meningkatkan kreativitas berpikir siswa.
\end{abstract}

Kata kunci: Penemuan Terbimbing; Kreativitas Berpikir Siswa

\section{Pendahuluan}

Dalam dunia pendidikan, kreativitas merupakan salah satu faktor penentu keberbakatan siswa. Menurut Munandar (2012), siswa yang mampu mengembangkan bakat dan kemampuannya secara optimal dapat mewujudkan diri dan berfungsi sepenuhnya sesuai dengan kebutuhan pribadi maupun kebutuhan masyarakat. Menurut Standar Isi dalam Permendiknas Nomor 22 Tahun 2006, mata pelajaran Matematika diberikan untuk membekali siswa dengan kemampuan berpikir logis, analitis, sistematis, kritis, dan kreatif, serta kemampuan bekerja sama. Kurikulum 2013 juga menyebutkan bahwa pembelajaran ditujukan untuk mengembangkan potensi peserta didik agar memiliki kemampuan hidup sebagai pribadi dan warga negara yang beriman, produktif, kreatif, inovatif, dan afektif, serta mampu berkontribusi pada kehidupan masyarakat, berbangsa, bernegara, dan berperadaban dunia. Dengan kata lain, kreativitas berpikir siswa memiliki peranan penting dalam pembelajaran matematika.

Kreativitas berhubungan dengan cara mengajar seorang guru (Munandar, 2012). Ini berarti bahwa guru berperan aktif dalam merancang suatu pembelajaran yang dapat meningkatkan kreativitas berpikir siswa. Siswa yang kreatif dapat menyelesaikan suatu permasalahan dengan menggunakan berbagai macam sudut pandang. Oleh karena itu, kreativitas sangat diperlukan siswa untuk mengembangkan daya berpikir siswa dalam menyelesaikan masalah terutama dalam mata pelajaran Matematika.

Berdasarkan hasil wawancara dengan guru matematika di SMPN 1 Turen, peneliti mendapat keterangan bahwa pembelajaran di sekolah masih cenderung menggunakan metode ceramah dan jarang sekali guru memberi masalah terbuka. Sedangkan berdasarkan hasil observasi awal oleh peneliti, didapatkan fakta bahwa kreativitas siswa kelas VIII-A kurang, yang tercermin dari jawaban siswa yang kurang bervariasi dan didukung oleh hasil 
pretes yaitu 51,8\% yang menyatakan bahwa kemampuan kreativitas siswa berada dalam kriteria "kurang baik".

Untuk mengatasi masalah tersebut, diperlukan suatu metode pembelajaran yang dapat meningkatkan kreativitas berpikir siswa. Pembelajaran yang diterapkan pada penelitian ini adalah Pembelajaran dengan Metode Penemuan Terbimbing. Pembelajaran menggunakan metode penemuan terbimbing merupakan salah satu jenis pembelajaran penemuan (discovery), yang melibatkan siswa dalam kegiatan belajar mengajar. Selain itu siswa juga memecahkan masalah secara mandiri dan mengembangkan ketrampilan-ketrampilan berpikir, karena mereka harus menganalisis dan memanipulasi informasi yang diberikan oleh guru mereka. Metode penemuan terbimbing dapat menumbuhkan rasa ingin tahu siswa, memberikan kesempatan siswa untuk menemukan konsep matematika, memberikan kesempatan untuk mengecek kembali apakah penemuan mereka sudah benar atau masih salah, serta memberikan kesempatan untuk menerapkan konsep matematika yang mereka temukan untuk menyelesaikan soal-soal yang disajikan. Berdasarkan uraian di atas penulis melakukan suatu penelitian yang menggunakan metode penemuan terbimbing untuk meningkatkan kreativitas siswa kelas VIII-A SMPN 1 Turen.

\section{Metode}

Penelitian tindakan yang direncanakan berupa penerapan pembelajaran menggunakan metode penemuan terbimbing. Menurut Arikunto,dkk (2010: 131), penelitian ini dilakukan dalam dua siklus. Masing-masing siklus terdiri dari empat komponen pokok, yaitu Perencanaan (Planning), Tindakan (Acting), Pengamatan (Observing), dan Refleksi (Reflecting).

Penelitian ini menuntut kehadiran peneliti di lapangan yang bertindak sebagai partisipan penuh, yakni sebagai peneliti, sebagai instrumen penelitian utama sekaligus sebagai pengumpul data. Kedudukan peneliti dalam penelitian ini dapat diartikan sebagai perencana, pelaksana, pengumpulan data, pengamat, penganalisisan, pelapor data, dan pelapor hasil penelitiannya. Oleh karena itu, peran seorang peneliti sangat mempengaruhi berhasil atau tidaknya keseluruhan usaha ini berjalan.

Dalam kegiatan pengamatan dan pengumpulan data, peneliti dibantu oleh guru bidang studi matematika kelas VIII SMP Negeri 1 Turen dan 1 rekan peneliti sebagai observer atau pengamat. Lokasi penelitian ini dilaksanakan di SMP Negeri 1 Turen, yang terletak di Jalan Panglima Sudirman I A Turen Kabupaten Malang. Waktu penelitian dilaksanakan pada semester I tahun ajaran 2014 - 2015 dengan pengambilan data pada bulan November 2014. Adapun yang menjadi subyek dalam penelitian ini adalah siswa kelas VIII-A yang berjumlah 31 siswa, terdiri dari 12 siswa laki-laki dan 19 siswa perempuan.

Adapun data yang diambil dari penelitian ini adalah dokumentasi berupa nilai hasil pretes sebagai acuan dalam mengukur bagaimana kemampuan berpikir kreatif siswa sebelumnya, hasil tes akhir siklus untuk mengetahui kemampuan berpikir kreatif siswa setelah diterapkannya pembelajaran dengan metode penemuan terbimbing, hasil observasi pengamat pada saat pembelajaran berlangsung bersama guru mata pelajaran matematika sebagai bahan analisis terhadap ketepatan guru (peneliti) dan siswa dalam menerapkan pembelajaran dengan metode penemuan terbimbing, dan hasil wawancara dengan siswa untuk mengetahui cara berpikir siswa apakah telah sesuai dengan indikator kemampuan berpikir kreatif dan mengetahui tanggapan siswa mengenai pembelajaran yang diterapkan. 


\section{Hasil dan Pembahasan}

\subsection{Hasil}

\subsubsection{Hasil Tindakan Siklus I}

Hasil observasi aktivitas guru dan siswa

Tabel 1 Hasil Observasi Aktivitas Guru Siklus I

\begin{tabular}{llll}
\hline \multirow{2}{*}{ Pertemuan Ke } & Observer & \multicolumn{2}{l}{ Observasi keterlaksanaaan aktivitas guru } \\
\cline { 2 - 4 } & & Presentase & Kategori \\
\hline I & I & $71 \%$ & Baik \\
\cline { 2 - 4 } & II & $77 \%$ & Baik \\
\hline II & I & $78,5 \%$ & Baik \\
\cline { 2 - 4 } & II & $78,5 \%$ & Baik \\
\hline Rata-rata & & $76,25 \%$ & Baik \\
\hline
\end{tabular}

Tabel 2 Hasil Observasi Aktivitas Siswa Siklus I

\begin{tabular}{llll}
\hline Pertemuan Ke & \multirow{2}{*}{ Observer } & \multicolumn{2}{l}{ Observasi keterlaksanaaan aktivitas siswa } \\
\cline { 2 - 4 } & & Presentase & Kategori \\
\hline \multirow{2}{*}{ I } & I & $72,7 \%$ & Baik \\
\cline { 2 - 4 } & II & $75 \%$ & Baik \\
\hline II & I & $77 \%$ & Baik \\
\cline { 2 - 4 } & II & $75 \%$ & Baik \\
\hline Rata-rata & & $74,8 \%$ & Baik \\
\hline
\end{tabular}

Berdasarkan tabel di atas, dapat disimpulkan bahwa aktivitas guru dan aktivitas siswa pada siklus I termasuk dalam kategori "baik".

\section{Kemampuan Kreativitas Siswa}

Tabel 3 Hasil kemampuan kreativitas berpikir siswa siklus I

\begin{tabular}{lll}
\hline No & Indikator Berfikir Kreatif & Presentase Keberhasilan \\
\hline 1 & Kelancaran & 85,5 \\
\hline 2 & Keluwesan & 66,5 \\
\hline 3 & Orisinal & 66,9 \\
\hline 4 & Memperinci & 85,8 \\
\hline Rata-rata & 76,2 \\
\hline
\end{tabular}

Data siklus I pada tabel di atas menunjukkan bahwa persentase keberhasilan untuk indikator kelancaran (fluency) mencapai $85,5 \%$, indikator keluwesan (fluency) mencapai 66,5\%, indikator kebaruan (originality) mencapai 66,9\%, dan indikator Memperinci (elaboration) mencapai 85,5\%.

\section{Hasil Wawancara}

Setelah pembelajaran pada siklus I selesai, guru mewawancarai 2 siswa untuk mendapatkan tanggapan mengenai pembelajaran yang telah diikuti oleh siswa. Secara umum siswa terlihat bersemangat mengikuti pembelajaran, namun pada awal pembelajaran siswa masih merasa kesulitan dengan tahapan-tahapan metode penemuan terbimbing. 
3.1.2. Hasil Tindakan Siklus II

Hasil observasi aktivitas guru dan siswa

Tabel 5 Hasil Observasi Aktivitas Guru Siklus II

\begin{tabular}{llll}
\hline \multirow{2}{*}{ Pertemuan Ke } & \multirow{2}{*}{ Observer } & \multicolumn{2}{l}{ Observasi keterlaksanaaan aktivitas siswa } \\
\cline { 2 - 4 } & & Presentase & Kategori \\
\hline \multirow{2}{*}{ I } & I & $80 \%$ & Baik \\
\cline { 2 - 4 } & II & $84 \%$ & Baik \\
\hline \multirow{2}{*}{ II } & I & $89 \%$ & Sangat Baik \\
\cline { 2 - 4 } & II & $91 \%$ & Sangat Baik \\
\hline Rata-rata & & $86 \%$ & Sangat Baik \\
\hline
\end{tabular}

Tabel 6 Hasil Observasi Aktivitas Guru Siklus II

\begin{tabular}{llll}
\hline \multirow{2}{*}{ Pertemuan Ke } & \multirow{2}{*}{ Observer } & \multicolumn{2}{l}{ Observasi keterlaksanaaan aktivitas siswa } \\
\cline { 2 - 4 } & & Presentase & Kategori \\
\hline I & I & $84 \%$ & Baik \\
\cline { 2 - 4 } & II & $88,6 \%$ & Sangat Baik \\
\hline \multirow{2}{*}{ II } & I & $88,6 \%$ & Sangat Baik \\
\cline { 2 - 4 } & II & $90 \%$ & Sangat Baik \\
\hline Rata-rata & & $87,8 \%$ & Sangat Baik \\
\hline
\end{tabular}

Berdasarkan tabel 5 dan tabel 6 di atas, dapat disimpulkan bahwa aktivitas guru dan aktivitas siswa pada siklus II termasuk dalam kategori "sangat baik"

Kemampuan Kreativitas Siswa

Tabel 7 Hasil hasil kemampuan kreativitas berpikir siswa Siklus II

\begin{tabular}{lll}
\hline No & Indikator Berfikir Kreatif & $\begin{array}{l}\text { Presentase } \\
\text { Keberhasilan }\end{array}$ \\
\hline 1 & Kelancaran & 95,5 \\
\hline 2 & Keluwesan & 83 \\
\hline 3 & Orisinal & 80 \\
\hline 4 & Memperinci & 94,7 \\
\hline Rata-rata & 88,3 \\
\hline
\end{tabular}

Data siklus II pada tabel di atas menunjukkan bahwa persentase keberhasilan untuk indikator kelancaran (fluency) mencapai 95,5\%, indikator keluwesan (fluency) mencapai 83\%, indikator kebaruan (originality) mencapai 80\%, dan indikator Memperinci (elaboration) mencapai 94,7\%.

\section{Hasil Wawancara}

Setelah pembelajaran pada siklus II selesai, guru mewawancarai 2 orang siswa yaitu siswa yang memiliki nilai rata-rata paling tinggi dan siswa yang memiliki rata-rata paling rendah untuk mendapatkan tanggapan mengenai pembelajaran yang telah diikuti oleh siswa. Siswa mengungkapkan setelah mengikuti pembelajaran dengan metode penemuan 
terbimbing, siswa menjadi lebih mudah memahami pelajaran. Setelah siswa terbiasa dengan metode penemuan terbimbing, siswa dapat mengerjakan soal dengan baik.

\section{Hasil Temuan Penelitian}

\section{Temuan pada siklus I}

- Aktivitas guru (peneliti) sebagai pelaku pelaksanaan pembelajaran dengan metode penemuan terbimbing secara keseluruhan masuk dalam kategori "baik".

- Aktivitas siswa sebagai subjek dalam pelaksanaan pembelajaran dengan metode penemuan terbimbing secara keseluruhan masuk dalam kategori "baik".

- Pembelajaran dengan metode penemuan terbimbing baru pertama kali diterapkan di kelas VIII-A SMP Negeri 1 Turen sehingga pada awal pertemuan siswa belum terbiasa menggunakan metode pembelajaran tersebut yang mengakibatkan siswa mengalami sedikit kesulitan dalam memahami materi.

- Pencapaian kreativitas berpikir siswa berdasarkan masing- masing indicator adalah sebagai berikut: kelancaran (fluency) 85,5\%, keluwesan (Flexibility) 66,5\%, Orisinil (originality) 66,9\%, dan memperinci (elaboration) 85,8\%. Hal tersebut menunjukkan bahwa kemampuan berpikir kreatif siswa mencapai 76,2\% dengan kategori "cukup baik".

\section{Temuan pada siklus II}

- Aktivitas guru (peneliti) sebagai pelaku pelaksanaan pembelajaran dengan metode penemuan terbimbing secara keseluruhan masuk dalam kategori "sangat baik".

- Aktivitas siswa sebagai subjek dalam pelaksanaan pembelajaran dengan metode penemuan terbimbing secara keseluruhan masuk dalam kategori "sangat baik"

- Pada siklus II, siswa kelas VIII-A SMP Negeri 1 Turen nampak sudah mulai terbiasa dengan pembelajaran dengan metode penemuan terbimbing, terlihat dari antusias siswa dalam berpartisipasi selama proses pembelajaran.

- Kreativitas berpikir siswa secara umum sudah nampak terlihat dari wawancara guru dengan beberapa siswa selama proses pembelajaran berlangsung.

- Pencapaian kreativitas berpikir siswa berdasarkan masing- masing indicator adalah sebagai berikut: kelancaran (fluency) 95,5\%, keluwesan (Flexibility) 83\%, Orisinil (originality), 80\%, dan memperinci (elaboration) 94,7\%. Hal tersebut menunjukkan bahwa kemampuan berpikir kreatif siswa meningkat mencapai 88,3\% dengan kategori "sangat baik".

\subsection{Pembahasan}

Kemampuan Kreativitas Matematis Siswa Kelas VIII-A SMP Negeri 1 Turen meningkat setelah mengikuti pembelajaran dengan metode penemuan terbimbing. Hal ini terlihat dari hasil yang diperoleh berdasarkan rata-rata nilai kemampuan berpikir kreatif siswa pada siklus II telah berhasil mencapai kriteria peningkatan kemampuan berpikir kreatif. 
Langkah-langkah guru dalam penerapan pembelajaran dengan metode penemuan terbimbing yang dapat meningkatkan kemampuan berpikir kreatif siswa sebagai berikut.

3.2.1.Guru memberi kesempatan pada siswa untuk memahami masalah yang ada pada Lembar kegiatan Siswa (Tahap observasi)

Pada siklus I, guru memberi kesempatan pada siswa untuk memahami masalah yang ada pada Lembar kegiatan Siswa, tetapi belum terlaksana dengan maksimal. Guru belum memaksimalkan pemberian masalah-masalah yang memiliki lebih dari satu jawaban kepada siswa sehingga kurang menggali kemampuan berpikir kreatif siswa.

Pada siklus II, guru memberikan masalah-masalah yang memiliki lebih dari satu jawaban. Pada kegiatan tersebut guru memberikan masalah-masalah yang dapat memunculkan alternatif cara yang bervariasi. Hal ini didukung oleh Siswono (2005:5) yang mengatakan bahwa kemampuan berpikir kreatif siswa terlihat ketika siswa memahami masalah dengan strategi atau metode yang bervariasi.

3.2.2.Guru memberi kesempatan pada siswa untuk membuat pertanyaan mengenai cara penyelesaian masalah yang ada pada LKS (Merumuskan masalah)

Pada siklus I, guru memberi kesempatan pada siswa untuk membuat pertanyaan berdasarkan masalah yang diberikan guru, tetapi belum terlaksana dengan maksimal. Siswa masih terlihat kurang terbiasa membuat pertanyaan sehingga masih perlu diberi contoh dan diberi arahan oleh guru agar pertanyaan yang dibuat sesuai dengan topik pembelajaran yang diajarkan.

Pada siklus II, guru memberi kesempatan pada siswa untuk membuat pertanyaan berdasarkan masalah yang diberikan guru. Pada kegiatan tersebut guru memberikan bimbingan-bimbingan yang dapat membantu siswa dalam merumuskan masalah dan memunculkan pertanyaan yang bervariasi. Pada tes akhir siklus II, terlihat terjadi peningkatan siswa saat membuat pertanyaan. Hal ini sesuai dengan indikator kreativitas yaitu kelancaran yang meningkat dari $85,5 \%$ menjadi $95,5 \%$.

3.2.3.Memberi kesempatan pada siswa merumuskan jawaban sementara dari pertanyaan yang telah mereka buat (Mengajukan hipotesis)

Pada siklus I, guru memberi kesempatan pada siswa untuk merumuskan jawaban sementara dari pertanyaan yang telah mereka buat, tetapi belum terlaksana dengan maksimal. Siswa masih terlihat kesulitan merumuskan jawaban sementara karena kurang terbiasa.

Pada siklus II, guru memberi kesempatan pada siswa untuk merumuskan jawaban sementara dari pertanyaan yang telah mereka buat. Pada kegiatan tersebut guru memberikan bimbingan-bimbingan yang dapat membantu siswa dalam merumuskan jawaban sementara yang bervariasi sesuai dengan pertanyaan yang telah mereka buat. Hal ini sesuai dengan indikator kreativitas yaitu keluwesan yang meningkat dari 66,5 \% menjadi 83\%, kreativitas berpikir siswa pada indikator kebaruan (originality) meningkat dari $66,9 \%$ menjadi $80 \%$, dan memperinci yang meningkat $85,8 \%$ menjadi $94,7 \%$. 
3.2.4.Memberi kesempatan pada siswa untuk merencanakan pemecahan masalah (Merencanakan pemecahan masalah)

Pada siklus I, guru memberi kesempatan pada siswa untuk merencanakan pemecahan masalah dari pertanyaan yang telah mereka buat, tetapi belum terlaksana dengan maksimal. Siswa masih terlihat kesulitan merencanakan pemecahan masalah dari pertanyaan yang telah mereka buat. Beberapa siswa terlihat melakukan perencanaan dengan cara yang sama sehingga aspek kreativitasnya masih terlihat belum tampak. Pada siklus II, guru memberi kesempatan pada siswa untuk merencanakan pemecahan masalah dari pertanyaan yang telah mereka buat Pada kegiatan tersebut guru memberikan bimbingan-bimbingan yang dapat membantu siswa dalam merencanakan pemecahan masalah dari pertanyaan yang telah mereka buat denganalternatif cara yang bervariasi sehingga dapat memunculkan aspek kreativitas bagi siswa. Pada tes akhir siklus II, terlihat terjadi peningkatan siswa saat merencanakan pemecahan masalah. Hal ini sesuai dengan indikator kreativitas yaitu keluwesan yang meningkat dari 66,5 \% menjadi 83\%, kreativitas berpikir siswa pada indikator kebaruan (originality) meningkat dari 66,9\% menjadi $80 \%$, dan memperinci yang meningkat $85,8 \%$ menjadi $94,7 \%$.

3.2.5.Memberi kesempatan pada siswa melakukan pemecahan masalah dengan mencari alternatif jawaban yang lain (Melaksanakan eksperimen)

Pada siklus I, guru memberi kesempatan pada siswa untuk melakukan pemecahan masalah, tetapi belum terlaksana dengan maksimal. Siswa masih melakukan pemecahan masalah dengan cara yang relatif sama. Hal ini menunjukkan kreativitas siswa dalam menyelesaikan suatu masalah masih kurang. Pada siklus II, guru memberi kesempatan pada siswa untuk melakukan pemecahan masalah dengan mencari alternatif jawaban yang lain. Pada kegiatan tersebut guru memberikan bimbinganbimbingan yang dapat membantu siswa dalam merencanakan pemecahan masalah dari pertanyaan yang telah mereka buat dengan alternatif cara yang bervariasi sehingga dapat memunculkan aspek kreativitas bagi siswa. Pada tes akhir siklus II, terlihat terjadi peningkatan siswa saat melakukan pemecahan masalah. Hal ini sesuai dengan indikator kreativitas yaitu keluwesan yang meningkat dari 66,5 \% menjadi 83\%, kreativitas berpikir siswa pada indikator kebaruan (originality) meningkat dari 66,9\% menjadi 80 $\%$, dan memperinci yang meningkat $85,8 \%$ menjadi $94,7 \%$.

3.2.6. Memberi kesempatan pada siswa untuk mendeskripsikan temuan yang diperoleh berdasarkan hasil pengujian hipotesis (Pengumpulan data dan analisis data)

Pada siklus I, guru memberi kesempatan pada siswa untuk melakukan pengumpulan data dan analisis data, tetapi belum terlaksana dengan maksimal. Siswa masih kesulitan mendeskripsikan temuan yang diperoleh berdasarkan hasil pengujian hipotesis karena belum terbiasa. Pada siklus II, guru memberi kesempatan pada siswa untuk mendeskripsikan temuan yang diperoleh berdasarkan hasil pengujian hipotesis. Pada kegiatan tersebut guru memberikan bimbingan-bimbingan yang dapat membantu siswa dalam mendeskripsikan temuan yang diperoleh berdasarkan hasil pengujian hipotesis. Pada tes akhir siklus II, terlihat terjadi peningkatan siswa saat melakukan 
pengumpulan data dan analisis data. Hal ini sesuai dengan indikator kreativitas yaitu memperinci yang meningkat dari $85,8 \%$ menjadi $94,7 \%$.

\section{Simpulan}

\subsection{Kesimpulan}

4.1.1. Berdasarkan paparan data, temuan penelitian dan pembahasan, dapat diperoleh kesimpulan sebagai berikut.

4.1.2. Penerapan pembelajaran dengan metode penemuan terbimbing dapat meningkatkan kemampuan kreativitas berpikir siswa kelas VIII-A SMPN 1 Turen. Hal ini ditunjukkan dengan peningkatan indikator kreativitas kelancaran (fluency) yang meningkat dari $85,5 \%$ menjadi $95,5 \%$, indikator kreativitas keluwesan (flexibility) yang meningkat dari 66,5 \% menjadi 83\%, indikator kreativitas kebaruan (originality) meningkat dari 66,9 \% menjadi 80\%, dan indikator kreativitas memperinci yang meningkat $85,8 \%$ menjadi $94,7 \%$.

4.1.3. Langkah-langkah pembelajaran dengan metode penemuan terbimbing dapat meningkatkan kemampuan kreativitas berpikir siswa kelas VIII-A SMPN 1 Turen adalah observasi, merumuskan masalah, mengajukan hipotesis, merencanakan pemecahan masalah, melaksanakan eksperimen, serta pengumpulan data dan analisis data.

\subsection{Saran}

\subsubsection{Bagi Pendidik}

4.2.1.1.Pembelajaran dengan metode penemuan terbimbing dapat digunakan sebagai alternatif pembelajaran yang tepat untuk membantu meningkatkan kemampuan kreativitas berpikir siswa.

4.2.1.2. Masalah-masalah yang memuat lebih dari satu jawaban (masalah terbuka) sebaiknya lebih sering diberikan kepada siswa untuk melatih kreativitas berpikir siswa.

4.2.2. Bagi peneliti selanjutnya, sebaiknya peneliti selanjutnya dapat menerapkan metode pembelajaran ini pada pokok bahasan yang berbeda.

\section{Daftar Rujukan}

Arikunto, S. (2010). Prosedur penelitian suatu pendekatan praktik, Jakarta: Rineka Cipta, Cet. Ke-13.

Markaban. (2006). Model pembelajaran matematika dengan pendekatan penemuan terbimbing. Yogyakarta: PPPG Matematika.

Munandar, U. (2012). Pengembangan kreativitas anak berbakat. Jakarta : PT Rineka Cipta.

Siswono, Tatag Yuli Eko. (2006). Pengembangan kriteria tingkat berpikir kreatif siswa dalam matematika, Jurnal Ilmu Pendidikan, vol. 13, no. 1, pp.1.

Nasional, K. P. (2010). Pedoman penulisan karya ilmiah: skripsi (doctoral dissertation, tesis, disertasi, artikel, makalah, tugas akhir, laporan penelitian (edisi kelima). Malang: Universitas Negeri Malang). 